\title{
COMPANY VALUE DETERMINANTS STUDY ON MANUFACTURING COMPANY LISTED IN INDONESIA STOCK EXCHANGE
}

\author{
Oyong Lisa *)
}

\begin{abstract}
The purpose of this study to determine the effect of firm size, leverage, and profitability to the value of companies in manufacturing companies listed on the Indonesia Stock Exchange (BEI) partially or simultaneously. This research tested the hypothesis that there is influence of firm size, leverage, and profitability to the value of companies in manufacturing companies listed on the Indonesia Stock Exchange (BEI). The sampling technique used was purposive sampling. The research method used is multiple linear regression statistic method.The results showed that firm size variables have no effect on firm value, leverage has no effect on firm value, profitability has positive influence to firm value. While simultaneously there is influence of firm size, leverage, and profitability to firm value with coefficient of determination (adjusted R2) obtained equal to 0,28, indicating that $28 \%$ company value can be influenced by firm size, leverage, and profitability, while side $72 \%$ The value of the company is influenced by the variables that are not examined in this research. The limitations of this study is to examine the effect of firm size, leverage, and profitability on firm value. While other variables that affect the value of the company is expected to be examined by further researchers.
\end{abstract}

Keywords: Firm Size, Leverage, Profitability, Corporate Value

\section{INTRODUCTION}

\subsection{Research Background}

Business entities are a gathering place of manpower, capital, natural resources and also entrepreneurship whose purpose is to earn the maximum profit. By maximizing profits, it can be ascertained that the company can maintain its survival and continue to grow so as to provide a profitable return for its owners in the welfare of the owners and also employees / workers who are in it.

The value of a company is the perception of investors in funding a company with consideration of the value of time and money against companies that are often associated with stock prices. The higher the stock price, the higher the shareholder wealth, maximizing shareholder wealth also means that management must maximize the present value of expected return in the future.

The size of a company is a symbol of a company's size. An established company will have easy access to the capital market to raise funds at a lower cost, while new and small companies will have many difficulties accessing the capital market.

Leverage is defined as an estimate of the risks inherent in a company. That is, the greater leverage indicates a greater investment risk as well. Firms with low leverage have a lower leverage risk. With the high leverage ratio shows that the company is not solvable means total debt is greater than the total assets. Because of leverage Is a ratio that calculates the extent of the funds provided by creditors, and also as a ratio comparing the total debt to the total assets of a company, it is feared with high assets of debt that will increase investment risk, if the company can not pay its obligations on time.

Profitability is a company's ability to generate profit in the future and is an indicator of the success of the company's operations. The investors investing shares in the company is to get a return, consisting of yield and capital gains. This means that the higher the ability to earn profits, the greater the expected return of investors so as to make the company's value to be better. 
Based on the description of the above background research aims to determine the effect of firm size on corporate value, leverage to the value of the company, profitability to the value of the company.

\subsection{Research Problem}

Research problem that proposed by researcher in this study is, is there any effect between firm size, leverage, and profitability toward the value of the company?

\subsection{Research Purpose}

This research aims to examine the level of influence of independent variables $(\mathrm{X})$ ie firm size, leverage and profitability to the dependent variable (Y) is the value of the company.

\section{THEORETICAL FRAMEWORK AND HYPHOTESIS DEVELOPMENT}

\subsection{Theoretical Framework}

\subsubsection{Agency Theory}

Agency Theory explains the relationship between agent (management company) and principal (shareholder). The relationship will occur whenever someone (the owner) will employ another party (agent) to represent his interests. In all agency relationships, there is a possibility of conflict of interest between the owner and his agent called agency problem (Daly, 2015; Boshkoska, 2015).

Agency problems usually occur because of the parties who have more information (agents) than with other parties (principal). Agents get more information because they deal directly with the company's operations. Assuming the individual has an interest for himself, then with the existence of information asymmetry will encourage the agent to hide information that is not owned by the principal.

\subsubsection{Signaling Theory}

This theory explains how a company should give a signal to users of financial statements about the condition of the company (Jogiyanto, 2016). This signal is in the form of information about the condition of the company to the owner or other interested parties. Signals can be made through the disclosure of accounting information such as financial statements, what reports have been done by management to realize the wishes of the owner, or even can be promotions and other information that states that the company is better than other companies.

Thus the management of any company that has go public must provide information to the investors so that they can know the state of the company and its prospects in the future. So in the decision to invest, investors can distinguish which companies have a good corporate value that will be profitable for investors. Because good corporate value can be shown by increasing stock prices from time to time.

\subsubsection{Company Value}

According to Brigham and Houston (2010) "corporate value is the primary goal of managerial decisions taking into account the risks and times associated with earnings forecasts for maximizing the price of the company's common stock".

Company value can be said to have a good value if the company's performance is also good. If the value of high shares can be said that the value of the company is also good. Because the main purpose of the company is to increase the value of the company through increasing the prosperity of owners or shareholders. Company value can be defined as the value of the company's wares describing investors' perceptions of the issuer.

Company value is also a benchmark company to know whether the company has reached its goal or not. Which in this case by increasing the stock price in the capital market, because with the high stock price it can be concluded that the value of his company is also high. 


\subsubsection{Company Size}

The size of the company describes the size of the company. The size of the company can be determined based on total sales, total assets, and average sales rate Company size is one of the variables considered in determining the value of the firm (Paramita, 2012). Company size is a reflection of total assets owned by the company. The larger the size of the company, means that the company's assets are larger and the funds required by the company to maintain its operational activities even more. The size of a company is a symbol of a company's size. An established company will have easy access to the capital market to raise funds at a lower cost, while new and small companies will have many difficulties accessing the capital market.

\subsubsection{Leverage}

One important factor in the financing element is leverage. Enekwe et al (2014) explains that leverage is a measure of how much firms use equity and debt to finance its assets. Companies that do not have leverage means using their own capital 100\%. Decision to take a financial leverage need to be calculated. Therofore, Akbarian (2013) states that leverage ratios contribute in measuring the risk of using equity costs.

According to Hery (2015) "solvency ratio (leverage) is the ratio used to measure the extent to which the company's assets are financed with debt. This means how much debt burden borne by the company compared to its assets ".Leverage is defined as an estimator of the inherent risk to a company. That is, the greater leverage indicates the risks of an increasingly large investment. Companies with low leverage ratios have a lower leverage risk. With the high ratio of leverage indicates that the company is not solvable means total debt is greater than the total assets.

\subsubsection{Profitability}

Profitability is the level of net profit that can be achieved by the company during the operation.According to Anugerah, Hutabarat, and Faradilla (2010) profitability is the company's ability to generate profit over a certain period. When a company has a high level of profit, the company (management) considers it unnecessary to report things that may disrupt information about the company's financial success (Jariah, 2016). Conversely, when profitability levels are low, they expect report users to read "good news" for the company, for example in the social sphere, and thus investors will continue to invest in the company. If the company's ability to generate profits increases, then the stock price will also increase. Profitability can reflect the advantages of financial investment, meaning that profitability affects the value of the firm because of the growing internal resources.

\subsection{Hyphotesis}

follows:

Based on the formulation of problems and objectives in this study, the hypothesis proposed as

H1: The size of the company has a significant effect on the value of the company in the manufacturing company listed on the Indonesia Stock Exchange.

$\mathrm{H} 2$ : Leverage has a significant effect on the value of the company in a manufacturing company listed on the Indonesia Stock Exchange.

H3: Profitability significantly affects the value of the company in manufacturing companies listed on the Indonesia Stock Exchange.

\section{RESEARCH METHOD}

\subsection{Research Design}

Researcher used an external data (secondary data) that obtained from the official website of the company that published at Indonesia Stock Exchange (BEI) Indonesian Capital Market Directory and IDX website www.idx.co.id. 2013-2015 period. 


\subsection{Population and Sample}

The population in this study is a manufacturing company listed on the Indonesia Stock Exchange (BEI) in the period 2013-2015. The total population in this study is 146 manufacturing companies. Sample selection method in this study is determined by purposive sampling, ie the sample companies based on certain criteria tailored to the objectives and research problems.

\subsection{Research Variables}

Table 1 Research Variables

\begin{tabular}{|c|c|}
\hline Variables & Definition \\
\hline Company Size (X1) & $\begin{array}{l}\text { A basic aspect that needs to be scrutinized in } \\
\text { investment decisions. The larger the size of the } \\
\text { company, the easier it is to access the information, in } \\
\text { other words the company's likelihood of obtaining } \\
\text { more funds than the company that has only the } \\
\text { information that is classified as less. }\end{array}$ \\
\hline Leverage (X2) & $\begin{array}{l}\text { The ratio used to measure the extent to which a } \\
\text { company's assets are financed with debt. This means } \\
\text { how much debt burden borne by the company } \\
\text { compared to its assets. In a broad sense it is said that } \\
\text { solvency ratio is used to measure the ability of a } \\
\text { company to pay all its obligations, both short and long } \\
\text { term if the company is dissolved. }\end{array}$ \\
\hline Profitability (X3) & $\begin{array}{l}\text { The ability of a company to generate profit over a } \\
\text { certain period that can be calculated based on sales, } \\
\text { assets or capital sendiri.Semakin profitability growth } \\
\text { means the prospect of the company in the future } \\
\text { assessed the better, meaning the value of the company } \\
\text { will also be rated better in the eyes of investors. }\end{array}$ \\
\hline Company Value (Y) & $\begin{array}{l}\text { The value of the company can be said to have a good } \\
\text { value if the company's performance is also good. If the } \\
\text { value of high shares can be said that the value of the } \\
\text { company is also good. Because the main purpose of } \\
\text { the company is to increase the value of the company } \\
\text { through increasing the prosperity of owners or } \\
\text { shareholders. Company value can be defined as the } \\
\text { value of the company's wares describing investors' } \\
\text { perceptions of the issuer. }\end{array}$ \\
\hline
\end{tabular}

\subsection{Research Framework}

Based on the explanation described above, it can be described the research model in the chart as follows:

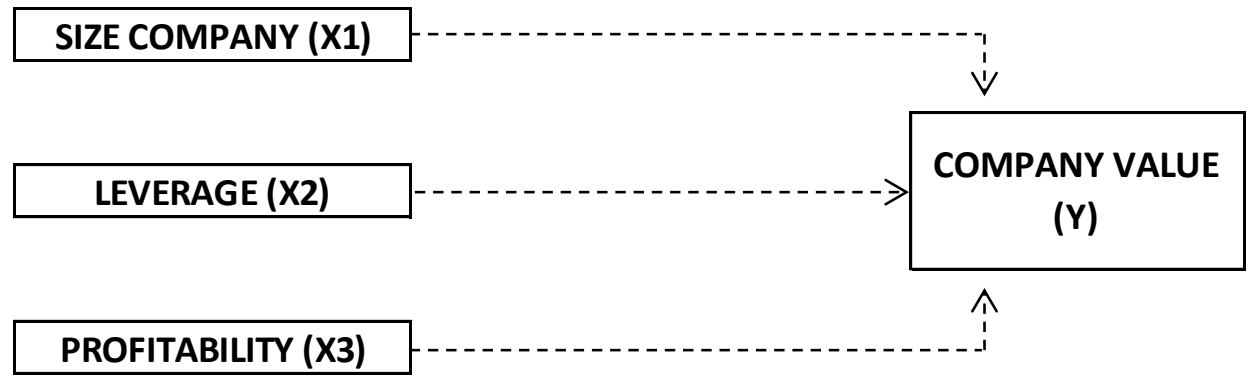

Picture 1 Research Framework 


\subsection{Type of Data and Sampling Method}

Data analysis techniques used in this study is multiple linear regression with the aim to examine the level of influence of independent variables (X) that consist of firm size, leverage and profitability to the dependent variable (Y), the value of the company

\section{RESEARCH RESULT AND ANALYSIS}

\subsection{Hypothesis Testing}

T-test is done to know how big influence of independent variable to dependent variable partially. The benchmark used is to compare $t$ arithmetic with $t$ table.

Table 2 T-Test

\begin{tabular}{|c|c|c|c|c|c|}
\hline \multirow[b]{2}{*}{ Model } & \multicolumn{2}{|c|}{ Unstandardized Coefficients } & \multirow{2}{*}{$\begin{array}{c}\begin{array}{c}\text { Standardized } \\
\text { Coefficients }\end{array} \\
\text { Beta }\end{array}$} & \multirow[b]{2}{*}{$\mathrm{t}$} & \multirow[b]{2}{*}{ Sig. } \\
\hline & B & Std. Error & & & \\
\hline 1 (Constant) & 531351.178 & 221071.165 & & 2.404 & .017 \\
\hline Company Size & 77717.864 & 34168.592 & .152 & 2.275 & .024 \\
\hline Leverage & 5132.904 & 1974.682 & .173 & 2.599 & .010 \\
\hline Profitability & 649.355 & 3014.760 & .114 & 2.215 & .030 \\
\hline
\end{tabular}

a. Dependent Variable: Value Company

Source: SPSS data is processed

a. The first hypothesis in this study is the size of the company positively affect the value of the company on manufacturing companies listed on the Indonesia Stock Exchange. Based on table 4.10 note that the coefficient of $\beta$ firm size is positive value of 777717,864 and the value of $t$ arithmetic $>t$ table value is $2,275>1,980$, with significant $0,024<0,05$. This means that firm size positively affects the value of the company in manufacturing companies listed on the Indonesia Stock Exchange. Thus the first hypothesis (H1) is accepted.

b. The second hypothesis in this research is Leverage has a significant effect on the value of the company in manufacturing companies listed on the Indonesia Stock Exchange. In table 4.10 note that the coefficient $\beta$ firm size is positive value of 5132.904 and $t$ count value $>t$ table value is $2.599>1,980$, with significant $0.010<0.05$. This means that the leverage proxied by DAR (X2) has an effect Positive to the value of the company at a manufacturing company listed on the Indonesia Stock Exchange. Thus the second hypothesis (H2) is accepted.

The third hypothesis in this study is the profitability has a significant effect on the value of companies in manufacturing companies listed on the Indonesia Stock Exchange. In table 4.10 note that the coefficient $\beta$ firm size is positive value of 649.355 and the value of $t$ arithmetic $>t$ value table that is 2,215>1,980, with significant $0,030<0,05$. This means that the profitability proxied by ROA (X3) has a positive effect on the value of the company in the manufacturing company listed on the Indonesia Stock Exchange. Thus the third hypothesis (H3) is accepted.

\subsection{Classic Assumption Test}

In regression analysis it is necessary to test the classical assumption aiming to know and test the feasibility of the regression model used in this research. There are 4 classical assumption test that has been done that is as follows: 
Table 3 Multicolonierity Test

Coefficients $^{\mathrm{a}}$

\begin{tabular}{|l|r|r|}
\hline \multirow{2}{*}{ Model } & \multicolumn{2}{|c|}{$\begin{array}{c}\text { Collinearity } \\
\text { Statistics }\end{array}$} \\
\cline { 2 - 3 } 1 (Constant) & Tolerance & VIF \\
\hline Company Size & .967 & 1.034 \\
Leverage & .678 & 1.475 \\
Profitability & .677 & 1.477 \\
\hline
\end{tabular}

Source: SPSS data is processed

Multicollonearity test result shows tolerance value of firm size variable that is 0,967 , for leverage that is 0,678 and for profitability that is 0,677 result show that tolerance value from independent variable is bigger than 0,10 . Meanwhile VIF value of firm size is 1.034 , leverage is 1.475 and profitability is 1.477 result is smaller than 10.00 . So it can be concluded that regression model is free from multicolonierity problem.

Table 4 Autocorrelation Test

\begin{tabular}{|l|r|r|r|r|r|}
\hline Model & \multicolumn{1}{|c|}{$\mathrm{R}$} & \multicolumn{1}{|c|}{ R Square } & \multicolumn{1}{|c|}{$\begin{array}{c}\text { Adjusted R } \\
\text { Square }\end{array}$} & $\begin{array}{c}\text { Std. Error of the } \\
\text { Estimate }\end{array}$ & $\begin{array}{c}\text { Durbin- } \\
\text { Watson }\end{array}$ \\
\hline 1 & $.213^{\mathrm{a}}$ & .045 & .033 & 607125.323 & 1.981 \\
\hline
\end{tabular}

A. Predictors: (Constant), profitability, leverage, firm size

B. Dependent Variable: company value

Source: SPSS data is processed

From autocorrelation test seen that Durbin-Watson value equal to 1,981 Based on number of sample that is $225(\mathrm{n})$ and number of independent variable $3(\mathrm{k}=3)$, hence obtained table DurbinWatson lower limit (dl) equal to 1,76086 and Durbin- Watson upper limit (du) of 1.79753. Because $\mathrm{du}<\mathrm{DW}<4$-du or $1.79753<1,981<2.20247$, it can be stated that there is no positive or negative autocorrelation in the regression equation in this study. So it can be concluded that the regression model that formed in this research is in autocorrelation free area. While The result of heteroedasticity test (table 4) shows that firm size, leverage, and profitability variable have sig value. 1,000 or greater than 0.05 so it can be concluded there is no indication of heterokedastisitas.

Table 5 Heterocedasticity Test

\section{Coefficients $^{\mathrm{a}}$}

\begin{tabular}{|c|c|c|c|c|c|c|}
\hline & & \multicolumn{2}{|c|}{$\begin{array}{c}\text { Unstandardized } \\
\text { Coefficients }\end{array}$} & \multirow{2}{*}{$\begin{array}{c}\begin{array}{c}\text { Standardized } \\
\text { Coefficients }\end{array} \\
\text { Beta }\end{array}$} & \multirow[b]{2}{*}{$\mathrm{t}$} & \multirow[b]{2}{*}{ Sig. } \\
\hline \multicolumn{2}{|c|}{ Model } & $\mathrm{B}$ & Std. Error & & & \\
\hline 1 & (Constant) & 1.65615 & .300 & & .000 & 1.000 \\
\hline & Company Size & .000 & .103 & .000 & .000 & 1.000 \\
\hline & Leverage & .000 & .060 & .000 & .000 & 1.000 \\
\hline & Profitability & .000 & .092 & .000 & .000 & 1.000 \\
\hline
\end{tabular}

a. Dependent Variable: AbsUt

Source: SPSS data is processed 
Table 6 Normality Test (One-Sample Kolmogorov-Smirnov Test)

\begin{tabular}{|ll|r|r|r|r|}
\hline & & Nilai Perusahaan & Ukuran Perusahaan & Leverage & Profitabilitas \\
\hline $\mathrm{N}$ & & 225 & 225 & 225 & 225 \\
Normal & Mean & 36.14 & 36.03 & 36.17 & 36.16 \\
Parameters & Std. Deviation & 20.115 & 20.168 & 20.246 & 20.082 \\
Most & Absolute & .053 & .055 & .056 & .053 \\
Extreme & Positive & .047 & .049 & .043 & .043 \\
Differences & Negative & -.053 & -.055 & -.056 & -.053 \\
\hline Kolmogorov-Smirnov Z & .796 & .825 & .844 & .793 \\
\hline Asymp. Sig. (2-tailed) & .551 & .504 & .474 & .556 \\
\hline
\end{tabular}

\section{Source: SPSS data is processed}

The result of normality test showed the result from kolmogrov-smirnovyaitu, for company value $=$ 0,796 , firm size $=0,825$, leverage $=0,844$, and profitability $=0,793$ from result showed that kolmogrov-smirnov> 0,05 then population is normal distribution.

\subsection{Research Discussion}

4.3.1 The size of the company significantly affects the value of the company in manufacturing companies listed on the Indonesia Stock Exchange

Discussion Hypothesis size of the company significantly influence the value of companies in manufacturing companies listed on the Indonesia Stock Exchange. Tests on firm size variables indicate that these variables affect the value of the company. This proves that the larger the size of the company means that the assets owned by the company is getting bigger, thus the management more freely in using the existing assets in the company. In this case the company is able to achieve sales greater than variable costs and fixed costs so that the company gets the amount of income before tax. The larger the size of the company will also affect management decisions in deciding what funding will be used by the company so that funding decisions can optimize the value of the company.

\subsubsection{Leverage has a significant effect on the value of companies in manufacturing companies listed on the Indonesia Stock Exchange}

Discussion Hypothesis leverage significant effect on the value of companies in manufacturing companies listed on the Indonesia Stock Exchange. Testing of leverage variables indicates that this variable affects firm value. This proves that the company uses its debt to finance its investment. By using the debt the company can optimize its operational activities to achieve sales targets that ultimately the company get a greater profit from its fixed expenses so that the owners of the company gain an increased profit. This shows that manufacturing companies that have low leverage ratios of the company can be interpreted solvable which means the total debt owned by the company is lower than the total assets. With low assets derived from debt that lead to low investment risk, because the company is able to pay off its obligations on time.

\subsubsection{Profitability significantly affects the value of companies in manufacturing companies listed on the Indonesia Stock Exchange}

Discussion The profitability hypothesis has a significant effect on the value of companies in manufacturing companies listed on the Indonesia Stock Exchange. The test of profitability variables indicates that this variable affects firm value. This result also shows that the company is able to obtain a level of net profit when conducting its operations. Thus the company (management) does not need to report things that may disturb information about 
The success of corporate finance. By looking at the growth of profitability in a company, investors can see that there is a good prospect in the future which is considered better .. So, profitability becomes a very important consideration in investment decisions. Thus profitability can reflect the advantages of financial investment, meaning that profitability affects the value of the company due to an increasingly large internal source.

\section{RESEARCH CONCLUSION, LIMITATION, AND RECOMMENDATION}

\subsection{Conclusion}

Based on the results of tests and analyzes that have been described previously, it can be concluded that the size of the company affects the value of the company in manufacturing companies listed on the Indonesia Stock Exchange. In this period the company has a large company size so that the company can maximize its operational activities that impact on sales increase rather than variable costs and fixed costs. Leverage affects the value of companies in manufacturing companies listed on the Indonesia Stock Exchange In this period, the company uses debt to finance its investment by optimizing its operational activities to obtain high sales. So the company is able to pay off its short-term debt with increased sales. Profitability affects the value of companies in manufacturing companies listed on the Indonesia Stock Exchange In this period the company obtained a net profit while running its operations. By looking at the growth of profitability in a company gives a positive signal for investors who will invest, because investors see good prospects in the future that is rated better the impact on increasing the value of the company.

\subsection{Limitation}

The use of manufacturer company that listed in Indonesian Stock Exchande (BEI) may consider as the limitations in this research (can't be generalized to other sectors). This research only uses three variables (company size, leverage, and profitability) to examine company value, therefore for future researchers who will conduct research on the same topic should use different variables and longer study period in order to obtain better research results.

\subsection{Recommendation}

With the limitations in the research, the researcher proposed the suggestions to companies should look at future prospects in terms of the current unstable level of profitability, especially in terms of firm size and leverage. With the results of this study investors should consider first before making an investment decision so that the variables of company size, leverage, and profitability can be used as one of the considerations in making investments.

\section{REFERENCES}

Akbarian, S. (2013). The Investigation Effect of Financial Leverage and Environment Risk on Performance Firms of Listed Companies in Tehran Stock Exchange 8(3): 249-255.

Anugerah, R., Hutabarat, R., and Faradilla, W. (2010). Pengaruh Ukuran Perusahaan, Leverage dan Profitabilitas Terhadap Pengungkapan Tanggung Jawab Sosial Perusahaan pada Perusahaan Manufaktur yang Listing di BEI. Jurnal Ekonomi, Vol. 18 No. 1. 66-78.

Brigham, Eugene F. and Houston, Joel F. (2010). Fundamentals of Financial Management. Boston : South-Western College Pub.

Boshkoska, Meri. (2015). The Agency Problem: Measures for Its Overcoming. International Journal of Business and Management, Vol. 10, No. 1; 2015.

Daly, Hounaida. (2015). Conflicts of Interest in Agency Theory: A Theoretical Overview. Global Journal of Human-Social Science: E Economics Vol 15 Issue 1 Version 1 Year 2015. 
Enekwe, Chinedu Innocent; Agu, Charles Ikechukwu and Eziedo Kenneth Nnagbogu. (2014). The Effect of Financial Leverage on Financial Performance: Evidence of Quoted Pharmaceutical Companies in Nigeria. IOSR Journal of Economics and Finance (IOSR-JEF) Volume 5, Issue 3 (Sep.-Oct. 2014), pp. 17-25.

Hery. (2015). Analisis Laporan Keuangan : Pendekatan Rasio Keuangan. Yogyakarta : CAPS.

Ikatan Akuntan Indonesia. 2009. Standar Akuntansi Indonesia. Jakarta : Salemba Empat.

Jariah, Ainun. (2016). Tindakan Perataan Laba pada Perusahaan Jasa di Indonesia dengan Ukuran Perusahaan, Rasio Profitabilitas, dan Leverage sebagai Variabel Pembeda. Jurnal Penelitian Ilmu Ekonomi WIGA, Vol.6 No. 2: 100-110.

Jogiyanto. (2010). Teori Protofolio \& Analisis Investasi. Edisi ke 7. Yogyakarta : BPEE.

Lisa, Oyong. (2011). Analisis Faktor-Faktor Yang Mempengaruhi Permintaan Jasa Audit Eksternal Pada Koperasi di Jawa Timur. Jurnal Penelitian Ilmu Ekonomi WIGA, Vol. 3 No. 1: 20880944.

Paramita, Ratna W.D. (2012). Pengaruh Firm Size Terhadap Earnings Response Coeficient (ERC) Dengan Voluntary Disclousure Sebagai Variabel Intervening: Studi pada Perusahaan Manufaktur yang Terdaftar di Bursa Efek Indonesia". Jurnal Penelitian Ilmu Ekonomi WIGA, Vol. 2 No. 1: 2088-0944.

*) Oyong Lisa, STIE Widyagama Lumajang 